SEGMEN Jurnal Manajemen dan Bisnis

Volume 17 No 2 Juli 2021

p-ISSN: 0216-938X e-ISSN: 2684-8414

\title{
PENGARUH WEBSITE QUALITY TERHADAP MINAT BELI PRODUK START UP BUSINESS MAHASISWA
}

\section{THE IMPACT OF WEBSITE QUALITY ON STUDENTS' INTEREST TO BUY START UP BUSINESS PRODUCTS}

\author{
Deandra Vidyanata \\ Universitas Ciputra, Surabaya, Indonesia \\ CitraLand CBD Boulevard, Made, Sambikerep, Surabay, Jawa Timur 67219 \\ deandra.vidyanata@ciputra.ac.id
}

\begin{abstract}
ABSTRAK
Tujuan dari penelitian ini adalah untuk mengetahui pengaruh kualitas website terhadap niat beli. Dalam penelitian ini kualitas website diperiksa dengan menggunakan dimensi WebQual, oleh karena itu variabel yang digunakan adalah kegunaan, kemudahan penggunaan, hiburan, dan hubungan komplementer. Proses pengumpulan data yang dibutuhkan dalam penelitian ini menggunakan metode purposive sampling dengan kriteria sampel individu yang pernah membeli dan mengunjungi website start up business. Penelitian ini menggunakan sampel sebanyak 85 responden. Metode analisis yang digunakan dalam penelitian ini adalah metode kuantitatif dengan analisis regresi linier berganda untuk mengetahui pengaruh variabel kegunaan, kemudahan penggunaan, hiburan dan hubungan komplementer terhadap niat beli. Ditemukan bahwa kegunaan berpengaruh positif terhadap niat beli serta hubungan hiburan dan komplementer yang berpengaruh positif terhadap niat beli. Sedangkan kemudahan penggunaan diketahui tidak berpengaruh signifikan terhadap niat beli.
\end{abstract}

Kata Kunci: kualitas website, kegunaan, kemudahan penggunaan, hiburan, hubungan saling melengkapi, niat beli

\begin{abstract}
The purpose of this research is to find out the impact of website quality towards purchase intention. In this research website quality is examined using the WebQual dimension, therefore the variables used are usefulness, ease of use, entertainment, and complementary relationships. The data collection process needed in this research using a purposive sampling method with sample criteria of individuals who have bought and visited start up business' website. This research uses a sample of 85 respondents. The analytical method used in this research is quantitative method with multiple linear regression analysis to find out the influence of the variables of usefulness, ease of use, entertainment and complementary relationships on purchase intention. It is found that the usefulness positively significant towards purchase intention as well as the entertainment and complementary relationship that have a positive influence on purchase intention. While the ease of use is known not to have a significant influence towards purchase intention.
\end{abstract}

Keywords: website quality, usefulness, ease of use, entertainment, complementary relationships, purchase intention 


\section{SEGMEN Jurnal Manajemen dan Bisnis \\ Volume 17 No 2 Juli 2021 \\ p-ISSN: 0216-938X e-ISSN: 2684-8414}

\section{PENDAHULUAN}

Perkembangan teknologi di era globalisasi dapat memberikan berbagai macam peluang dan kesempatan bisnis, namun di sisi lain hal tersebut dapat membuat persaingan dalam dunia bisnis pun menjadi lebih ketat. Perkembangan teknologi menyebabkan perusahaan dituntut untuk selalu memanfaatkan teknologi dalam proses bisnisnya, salah satunya dengan memanfaatkan online website. Online website digunakan perusahaan dengan harapan para calon konsumen dapat mencari informasi yang lebih lengkap tentang produk dan menimbulkan minat untuk melakukan pembelian melalui website tersebut.

Pemanfaatan teknologi khususnya penggunaan online website untuk memasarkan produk didukung dengan data dari survei yang telah dilakukan, dimana Indonesia berada di peringkat ke-6 sebagai negara dengan pengguna internet terbesar di dunia. Hal ini dapat dilihat di gambar 1.1 dan gambar 1.1 dimana ada peningkatan jumlah pengguna internet di Indonesia yang cukup signifikan dari tahun 2017 - 2020, dan diprediksi masih akan mengalami peningkatan sampai dengan tahun 2023.

\section{Gambar 1}

\section{Proyeksi Pengguna Internet di Indonesia 2017 - 2023}

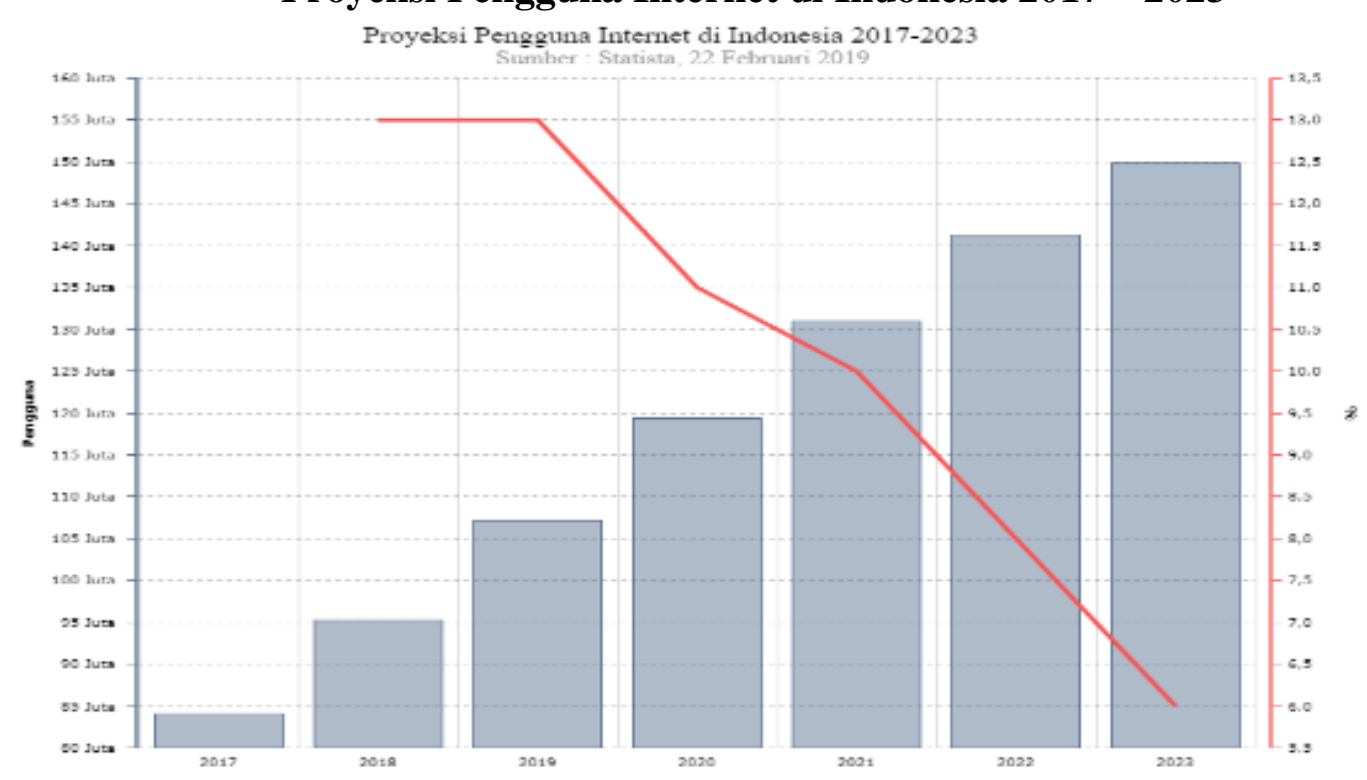

Berdasarkan data tersebut dapat disimpulkan bahwa terdapat potensi yang sangat tinggi dalam penggunaan teknologi termasuk di antaranya adalah website sebagai sarana pemasaran sebuah bisnis, terutama dengan semakin mudahnya akses internet dan banyaknya jumlah pengguna internet di Indonesia. Hal ini didukung oleh pernyataan Jeon \& Jeong (2017) dimana website dikatakan sebagai alat yang berguna dalam mempromosikan produk dan jasa. Sejalan dengan pernyataan tersebut, website juga dinyatakan secara efektif mampu meningkatkan minat beli calon konsumen (Ali, 2016; Akram, et al., 2017).

Kemampuan website sebagai alat promosi perusahaan salah satunya dapat diukur dengan menggunakan WebQual. Kualitas website (webQual) diartikan sebagai overall excellence or effectiveness of a 


\section{SEGMEN Jurnal Manajemen dan Bisnis \\ Volume 17 No 2 Juli 2021 \\ p-ISSN: 0216-938X e-ISSN: 2684-8414}

website in delivering intended messages to its audience and viewers (Jeong et al., 2003). Tidak hanya itu WebQual juga dinyatakan sebagai konstruksi multi-dimensi yang kompleks dan diusulkan untuk menilai desain situs web (Ahmad et al., 2007). Dengan demikian, dapat disimpulkan bahwa kualitas dari website bergantung dari keefektifan website tersebut dalam menyampaikan informasi yang dibutuhkan konsumen.

WebQual adalah salah satu ukuran yang digunakan untuk mengukur kualitas website dan terdiri dari faktor usefulness, ease of use, entertainment, serta complementary relationship (Loiacono et al., 2007). Usefulness dapat dinyatakan sebagai suatu persepsi dari seseorang yang menganggap bahwa menggunakan suatu sistem akan meningkatkan performa pekerjaan mereka, sementara itu ease of use dapat diartikan sebagai kondisi dimana seorang pengguna merasa bahwa menggunakan suatu sistem atau aplikasi tidak akan menyulitkan atau bebas dari usaha apapun (Davis, 1989). Entertainment berkaitan dengan stimuli yang disediakan oleh suatu website untuk menyediakan rasa nyaman dan menyenangkan saat menjelajah situs web (Rezende et al., 2017). Complementary relationship merupakan faktor pelengkap yang berfokus pada hubungan jangka panjang antara seorang pengguna dengan website perusahaan.

Purchase intention (minat beli) merupakan salah satu faktor penting yang harus diperhatikan perusahaan dalam meningkatkan penjualan, karena purchase intention merupakan gambaran dari kesan retensi (ingatan) konsumen. Menurut Ajzen dan Fisbein (1980), niat (intention) merupakan prediktor terbaik dari actual behavior. Niat berperilaku diasumsikan dapat menggambarkan faktor-faktor motivasional yang mempengaruhi tindakan seseorang dan indikasi seberapa besar usaha seseorang untuk melakukan suatu tindakan (Fishbein and Ajzen, 1975).

Minat beli menurut Crescimanno et al. (2016) merupakan sebuah kemungkinan konsumen akan membeli sebuah produk atau jasa. Sehingga dapat dinyatakan bahwa minat beli merupakan keinginan atau minat dari konsumen untuk melakukan pembelian akan produk atau jasa. Hal ini yang akan diteliti lebih lanjut apakah benar variabel kualitas website mempengaruhi minat beli.

Meskipun demikian, beberapa penelitian mendapatkan hasil yang berbeda tentang pengaruh kualitas website terhadap minat pembelian. Penelitian yang dilakukan oleh Rahmawati et al., (2018) menghasilkan kesimpulan bahwa kualitas website memang memiliki pengaruh terhadap minat beli, namun untuk beberapa dimensi dari kualitas website seperti usefulness dianggap tidak signifikan dalam mempengaruhi minat beli, begitu juga untuk ease of use dan enjoyment yang ditemukan tidak berpengaruh secara signifikan terhadap minat beli (Liat \& Wuan, 2014). Dengan demikian, dapat disimpulkan bahwa masalah yang melatarbelakangi dilakukannya penelitian ini yaitu belum adanya kejelasan mengenai apakah kualitas website mampu meningkatkan purchase intention. Berdasarkan latar belakang yang telah diuraikan tersebut, urgensi dari penelitian ini adalah untuk mengetahui pengaruh kualitas website terhadap minat pembelian produk start up business mahasiswa. 


\section{SEGMEN Jurnal Manajemen dan Bisnis \\ Volume 17 No 2 Juli 2021 \\ p-ISSN: 0216-938X e-ISSN: 2684-8414}

TECHNOLOGY ACCEPTANCE MODEL (TAM)

Technology acceptance model (TAM) merupakan sebuah model yang dibuat untuk memprediksi penerimaan teknologi oleh pengguna Davis (1986). TAM didasarkan pada paradigma sikap dan perilaku kognitif dari psikologi, dan dikhususkan untuk digunakan di bidang sistem informasi untuk memprediksi penerimaan dan penggunaan sistem informasi di pekerjaan individual pemakai.

Davis (1989) berpendapat bahwa orangorang memakai suatu sistem terutama karena fungsinya, dan kedua karena kemudahan atau kesulitan yang berhubungan dengan fungsi dalam penggunaan sistem tersebut. Model TAM meliputi 2 konstruk utama yaitu persepsi kegunaan (perceived usefulness) dan persepsi kemudahan penggunaan (perceived ease of use). TAM beragumentasi bahwa penerimaan individual terhadap sistem teknologi informasi ditentukan oleh dua konstruk tersebut. Pemakai teknologi akan mempunyai niat menggunakan teknologi jika pada awal penggunaannya merasa bahwa sistem dari teknologi tersebut bermanfaat dan mudah digunakan.

\section{KUALITAS WEBSITE (WEBQUAL)}

Kualitas website dapat didefinisikan sebagai keunggulan secara keseluruhan atau keefektifan suatu situs web dalam menyampaikan pesan-pesan yang dimaksudkan kepada audiens dan pemirsa (Jeong et al, 2003). Selain dari itu unsur penting dari website juga dibandingkan layaknya toko online dari sebuah perusahaan dimana perusahaan harus mengandalkan atribut dalam website supaya calon pembeli memutuskan melakukan pembelian (Tsao, et $a l, 2016)$. Beberapa studi lain yang mencoba untuk mengukur website dengan dimensidimensi tertentu menyatakan bahwa kualitas website sebagai konstruksi multi dimensi yang kompleks, yang diusulkan untuk menilai desain situs web (Ahmad et al, 2007). Kualitas website akan diteliti menggunakan variabel dari dimensi WebQual (Loiacono et al., 2007), yang meliputi variabel usefulness, ease of use, entertainment dan complementary relationship.

\section{USEFULNESS}

Usefulness memiliki definisi "the degree which a person believes that using a particular system would enhance his or her job performance" (Davis, 1989). Usefulness dapat dinyatakan sebagai suatu persepsi dari seseorang yang menganggap bahwa menggunakan suatu sistem akan meningkatkan performa pekerjaan mereka. Usefulness sendiri berdasarkan pernyataan Loiacono et al. (2007) dapat terbagi menjadi 2 yaitu usefulness on gathering information beserta usefulness on carrying out transactions. Usefulness memiliki 4 indikator berdasarkan Rezende et al. (2017) yang meliputi informational fit-to-task, tailored information, trust dan response time.

Informational fit-to-task berdasarkan Rezende et al. (2017) dinyatakan sebagaimana sebuah informasi berguna untuk pengguna (dalam meningkatkan performa atau berhubungan dengan pekerjaan). Tailored information, memiliki pengertian bahwa informasi dapat disesuaikan dengan kebutuhan pengguna. Trust, yang diartikan ketika komunikasi antar pengguna dan website dijamin aman dan privasi pengguna terjaga. Terakhir merupakan response time, yang diartikan 


\section{SEGMEN Jurnal Manajemen dan Bisnis \\ Volume 17 No 2 Juli 2021 \\ p-ISSN: 0216-938X e-ISSN: 2684-8414}

sebagai respon atau jangka waktu dari interaksi ataupun permintaan pada situs web.

\section{EASE OF USE}

Ease of use sendiri memiliki definisi "the degree to which the prospective user expects the target system to be free of effort" (Davis et al., 1989). Ease of use sendiri merupakan salah satu faktor yang diteliti dalam Technology Acceptance Model (TAM), dan secara kontekstual meliputi beberapa faktor seperti informasi apakah mudah dibaca dan dimengerti, kemudahan dalam operasi dan juga kemudahan dalam navigasi khususnya dalam kaitannya dengan website. Rezende et al. (2017) memiliki 2 indikator yaitu ease of understanding dan intuitive operations. Rezende et al. (2017) mengartikan indikator ease of use sebagai berikut, Ease of understanding memiliki pengertian berupa informasi dinyatakan mudah untuk dimengerti oleh pengguna situs web. Sementara intuitive operations, diartikan sebagai kondisi dimana mudah bagi pengguna untuk mengoperasikan atau bernavigasi dalam situs web

\section{ENTERTAINMENT}

Entertainment diartikan sebagai sebuah stimuli yang dapat menyediakan pengalaman nyaman dan menyenangkan disaat menjelajah situs web (Rezende et al., 2017). Konsep dari entertainment fokus akan bagaimana sikap seorang konsumen terutama dalam mengakses situs web belum tentu memiliki minat untuk melakukan transaksi apapun tetapi mereka ingin dihibur di dalam proses apapun termasuk saat sedang melakukan scrolling di website (Loiacono et al., 2007). Berdasarkan pernyataan Loiacono et al. (2007) "website must create a pleasant experience, it must be visually appealing, innovative flare and emotionally appealing ", dimana secara tidak langsung dalam segi entertainment atau hiburan, situs web harus mampu menciptakan suasana browsing yang baru serta menghibur bagi para penggunanya.

\section{COMPLEMENTARY RELATIONSHIP}

Complementary relationship merupakan salah satu faktor yang digunakan sebagai dimensi penentu kualitas website, dan cenderung berguna sebagai faktor pelengkap. Complementary relationship berdasarkan Rezende et al. (2017) memiliki 3 indikator yaitu consistent image, on-line completeness dan relative advantage. Berdasarkan Rezende et al. (2017) consistent image diartikan sebagai gambaran perusahaan baik di situs web maupun media lain tetap konsisten. On-line completeness, diartikan sebagai ketersediaan fitur-fitur utama ataupun pelengkap dalam situs web. Indikator terakhir merupakan relative advantage, yang memliki pengertian hubungan ke perusahaan melalui situs web lebih baik daripada media lain (telepon, fax).

\section{PURCHASE INTENTION}

Purchase intention menggambarkan tindakan konsumen di masa depan yang dapat diprediksi dan kemungkinan bahwa minat tersebut akan diwujudkan menjadi tindakan pembelian, baik secara offline maupun online (Kim et al., 2009). Lebih jauh lagi, Jamieson dan Bass (1989) menjelaskan bahwa purchase intention merupakan perilaku konsumen yang dapat diprediksi akan terjadi dalam waktu dekat mengenai pembelian dari suatu produk. Dengan demikian dapat disimpulkan bahwa purchase intention meliputi minat seseorang untuk membeli suatu produk, terlepas dari apakah 


\section{SEGMEN Jurnal Manajemen dan Bisnis \\ Volume 17 No 2 Juli 2021 \\ p-ISSN: 0216-938X e-ISSN: 2684-8414}

seseorang sudah pernah ataupun belum pernah membeli suatu produk.

Minat beli dapat diartikan sebagai salah satu kondisi dimana seorang konsumen mempertimbangkan atau memiliki niat untuk melakukan pembelian akan suatu produk maupun jasa. Hal ini didukung oleh pernyataan Sitanggang \& Hidayat (2018), dimana dinyatakan bahwa minat beli merupakan sebuah kemungkinan yang ada dalam konsumen ketika akan membeli sebuah produk atau jasa. Menurut Septanto \& Haryono (2018), minat beli memiliki definisi sebagai kecenderungan konsumen untuk membeli suatu merek atau mengambil tindakan berupa pembelian dan dapat diukur dengan kemungkinan konsumen akan melakukan pembelian.

\section{HUBUNGAN ANTAR VARIABEL}

\section{Hubungan antar variabel Usefulness} Terhadap Minat Beli

Usefulness didefinisikan sebagai kemungkinan seorang pengguna ketika menggunakan suatu sistem dapat meningkatkan performa pekerjaannya. Usefulness sendiri seringkali dilihat pengaruhnya baik dalam minat pembelian, kualitas website, loyalitas, penggunaan website kembali (Raad et al., 2018; Athapaththu \& Kulathunga., 2018; Loiacono et al., 2007). Penelitian Liat \& Wuan (2014) menemukan bahwa usefulness memiliki pengaruh signifikan terhadap minat beli dan sesuai dengan beberapa penelitian sebelumnya (Liat \& Wuan, 2014). Berdasarkan keterhubungan variabel disusunlah sebuah hipotesis untuk variabel usefulness, sebagai berikut:

$H_{1}$ : Usefulness memiliki pengaruh signifikan terhadap minat beli

\section{Hubungan antar variabel Ease of Use Terhadap Minat Beli}

Ease of use seperti usefulness merupakan variabel yang dikemukakan dalam teori TAM (Technology Acceptance Model), dimana ease of use didefinisikan sebagai sebuah tingkat dimana seorang pengguna mengharapkan sistem yang digunakan bebas dari usaha (free of effort). Ease of use juga seringkali dibahas dalam beberapa penelitian khususnya meliputi faktor yang mempengaruhi minat pembelian secara online, serta tergolong sebagai salah satu instrumen dalam WebQual (Rahmawati et al., 2018; Raad et al., 2018; Loiacono et al., 2007). Ease of use sendiri memiliki hasil pengaruh yang berbeda dalam beberapa penelitian, pada penelitian Liat \& Wuan (2014) ease of use tidak memiliki dampak yang signifikan terhadap minat pembelian. Sebaliknya berdasarkan penelitian lain (Raad et al., 2018; Rahmawati et al., 2018) ease of use memiliki pengaruh yang signifikan terhadap minat beli. Berdasarkan keterhubungan variabel disusunlah sebuah hipotesis untuk variabel ease of use, sebagai berikut:

\section{$\mathrm{H}_{2}$ : Ease of use memiliki pengaruh signifikan terhadap minat beli}

\section{Hubungan antar variabel Entertainment terhadap Minat Beli}

Entertainment merupakan salah satu instrumen yang digunakan untuk menilai kualitas website dalam WebQual (Loiacono et al., 2007). Berdasarkan penelitian Rahmawati (2018) entertainment dinyatakan memiliki dampak tidak langsung terhadap minat beli. Hal ini didukung dimana faktor entertainment secara signifikan mempengaruhi kepuasan pengguna, yang 


\section{SEGMEN Jurnal Manajemen dan Bisnis \\ Volume 17 No 2 Juli 2021 \\ p-ISSN: 0216-938X e-ISSN: 2684-8414}

kemudian secara tidak langsung kepuasan pengguna mempengaruhi minat beli. Berdasarkan keterhubungan variabel disusunlah sebuah hipotesis untuk variabel entertainment, sebagai berikut:

H3: Entertainment memiliki pengaruh signifikan terhadap minat beli

4. Hubungan antar variabel

Complementary Relationship terhadap Minat Beli

Complementary relationship merupakan instrumen terakhir dalam WebQual yang meliputi consistent image, on-line completeness dan relative advantage (Loiacono et al., 2007). Complementary relationship dalam penelitian Rahmawati (2018) dilihat signifikansi pengaruhnya terhadapan kepuasan individu yang kemudian kepuasan individu memiliki dampak tidak langsung terhadap minat beli.
Complementary relationship dalam penelitian ini akan dilihat pengaruhnya apakah signifikan atau tidak terhadap minat beli terlebih dengan complementary relationship mencakup hal seperti kemudahan melakukan aktivitas dalam website. Berdasarkan keterhubungan variabel disusunlah sebuah hipotesis untuk variabel complementary relationship, sebagai berikut: H4: Complimentary Relationship memiliki pengaruh signifikan terhadap minat beli

\section{MODEL EMPIRIS}

Model empiris adalah bentuk simbol dari suatu teori model kausal yaitu model menunjukkan hubungan kausal antara variabel-variabel. Pada penelitian ini mengembangan model empiris yang digambarkan seperti pada gambar berikut.

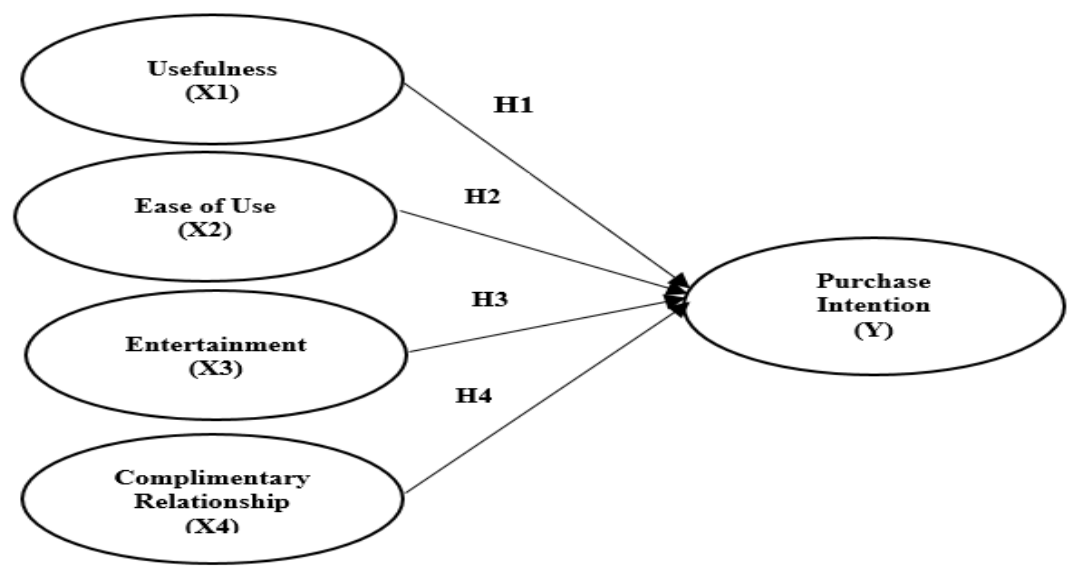

Gambar 2

Model Empiris

\section{METODE PENELITIAN}

Bisnis yang digunakan dalam penelitian ini adalah top 3 bisnis terbaik selama periode Januari - Juli 2019, hal ini disebabkan karena proses pembelajaran selama periode tersebut menggunakan metode awarding system. Sehingga diyakini bahwa proses pembelajaran dengan awarding system ini dapat memicu mahasiswa untuk memberikan usaha yang terbaik. Maka dari itu 3 project 


\section{SEGMEN Jurnal Manajemen dan Bisnis \\ Volume 17 No 2 Juli 2021 \\ p-ISSN: 0216-938X e-ISSN: 2684-8414}

business terbaik akan digunakan dalam penelitian ini. Adapun proses pengumpulan data dalam penelitian ini mengambil 30 responden yang merupakan customer dari masing-masing project business bisnis, dengan tingkat pengembalian kuesioner (response rate) 94\%. Peneliti melakukan sampling dengan menggunakan teknik nonprobability sampling serta menggunakan purposive sampling, dimana kriteria yaitu customer yang pernah membeli produk salah satu dari ketiga business tsb melalui website.

Proses pengangkaan sangat penting untuk memudahkan analisis kebermaknaan dan pengaruh dari masing-masing variabel, untuk itu terhadap data jawaban responden yang berupa tindakan dan pendapat dilakukan pengkodean menggunakan skala Likert (skor 1 - 5) dengan pernyataan yang bersifat mendukung atau memihak. Skala Likert merupakan skala yang dibentuk untuk menjelaskan seberapa kuat subjek disetujui atau tidak disetujui dengan 5 (lima) poin pertanyaan (Sekaran, 2006). Hal ini dilakukan karena analisis dan pengujian hipotesis dengan menggunakan alat statistika, maka data hasil riset yang berupa tindakan, pendapat atau kalimat-kalimat harus dikuantifikasikan dengan melakukan pengkodean mulai dari angka 1 yaitu sangat tidak setuju sampai dengan angka 5 yaitu sangat setuju.

\section{Uji validitas}

Uji validitas yang digunakan pada penelitian yaitu metode Korelasi Pearson dimana berdasarkan (Priyatno, 2014), penilaian validitas menggunakan kriteria tingkat signifikansi 0,05 dengan uji 2 sisi dan jika nilai $r$ hitung $\geq r$ tabel maka item dinyatakan valid, sebaliknya jika $r$ hitung $<r$ tabel maka item dinyatakan tidak valid. Mengikuti kriteria sebagai berikut jika tingkat signifikansi $<0,05$ maka item dinyatakan valid. Berdasarkan hasil perhitungan dapat disimpulkan bahwa semua variabel usefulness, ease of use, entertainment, complementary relationship dan minat beli yang digunakan sebagai alat ukur dalam kuesioner dinyatakan valid.

\section{Uji reliabilitas}

Uji reliabilitas yang digunakan pada penelitian ini yaitu cronbach's alpha dimana berdasarkan Priyatno (2014) jika nilai cronbach's alpha $\geq 0,60$ maka data dinyatakan reliabel namun jika nilai cronbach's alpha $<0,60$ maka data dinyatakan tidak reliabel. Berdasarkan hasil perhitungan dapat disimpulkan bahwa semua variabel yang digunakan dalam penelitian ini yaitu usefulness, ease of use, entertainment, complementary relationship dan minat beli yang digunakan sebagai alat ukur dalam kuesioner dinyatakan reliable.

Setelah dilakukan pengujian lebih lanjut, variabel yang digunakan dalam ini juga sudah terbebas dari 4 uji asumsi klasik yang terdiri dari uji normalitas, uji multikolinearitas, uji heterokedastisitas, dan uji linearitas, sehingga dapat disimpulkan bahwa pengujian hipotesis dapat dilakukan. Pengujian hipotesis dilakukan untuk mengetahui pengaruh variabel usefulness, ease of use, entertainment, dan complementary relationship terhadap purchase intention.

\section{ANALISIS HASIL DAN PEMBAHASAN}

Hasil pengujian pengaruh langsung untuk hipotesis pertama sampai dengan hipotesis keempat dengan menggunakan SPSS ditunjukkan pada tabel 1 berikut : 


\section{SEGMEN Jurnal Manajemen dan Bisnis \\ Volume 17 No 2 Juli 2021 \\ p-ISSN: 0216-938X e-ISSN: 2684-8414}

\section{Tabel 1}

Hasil Pengujian Hipotesis

\begin{tabular}{cccc}
\hline Hipotesis & Hubungan & $p$-values & Keterangan \\
\hline $\mathrm{H} 1$ & Usefulness $\rightarrow$ Minat Beli & 0,026 & Sig \\
\hline $\mathrm{H} 2$ & Ease of use $\rightarrow$ Minat Beli & 0,870 & Tidak Sig \\
\hline $\mathrm{H} 3$ & Enjoyment $\rightarrow$ Minat Beli & 0,017 & Sig \\
\hline $\mathrm{H} 4$ & Complimentary relationship $\rightarrow$ Minat Beli & 0,000 & Sig \\
\hline
\end{tabular}

Sumber : Data diolah (2020)

Berdasarkan tabel tersebut dapat disimpulkan bahwa 3 hipotesis penelitian yang telah dirumuskan yaitu $\mathrm{H} 1, \mathrm{H} 3$, dan $\mathrm{H} 4$ diterima dan 1 hipotesis yaitu $\mathrm{H} 2$ ditolak.

\section{Pengaruh Usefulness Terhadap Minat Beli}

Berdasarkan hasil uji $t$ dapat diketahui bahwa dalam penelitian ini variabel usefulness memiliki pengaruh signifikan terhadap variabel minat beli. Hasil uji t pada penelitian ini memenuhi hipotesis pertama yang dibuat yaitu usefulness memiliki pengaruh signifikan terhadap minat beli sehingga hipotesis ini dapat diterima. Hasil dari penelitian ini mendukung penelitian terdahulu Sari dan Setiaboedhi (2017), dan Oentario et al. (2017) yang menyatakan bahwa usefulness memiliki pengaruh signifikan terhadap minat beli. Usefulness berpengaruh terhadap minat beli dikarenakan terdapat beberapa aspek dalam usefulness yang dapat mendorong timbulnya minat beli seorang konsumen, salah satunya berdasarkan Loiacono et al. (2007) dimana usefulness secara garis besar meliputi usefulness on gathering information serta usefulness on carrying out transactions. Usefulness on carrying out transactions mengimplikasikan bahwa kemampuan sebuah website untuk menyediakan hal yang dapat menunjang transaksi dinilai berguna bagi konsumen hal ini sesuai dengan Loiacono et al. (2007) yang menyatakan bahwa salah satu dimensi yang berkaitan dengan usefulness carrying out transactions meliputi kepercayaan konsumen dan waktu respon yang diharapkan.

Kepercayaan dan respon waktu dikategorikan dalam usefulness dikarenakan dari aspek kepercayaan dapat membentuk persepsi konsumen bahwa suatu sistem bermanfaat bagi mereka namun jika tidak ada unsur kepercayaan maka timbul kemungkinan konsumen merasa bahwa sistem tidak bermanfaat. Selain dari itu aspek kepercayaan juga meliputi bagaimana konsumen dapat mempercayai website untuk menjaga informasi serta keamanan yang diberikan dalam transaksi. Sementara respon waktu diimplikasikan jika respon waktu dari suatu website sangat lama maka konsumen cenderung tidak akan betah mengunjungi website serta tidak akan menggunakan website tersebut, hal ini didukung berdasarkan penelitian Loiacono et al. (2007), Rezende et al. (2017)

Hal tersebut secara tidak langsung mengimplikasikan bahwa kualitas website yang baik khususnya dalam aspek kegunaan/usefulness di mata konsumen harus meliputi kemampuan untuk menjaga 


\section{SEGMEN Jurnal Manajemen dan Bisnis \\ Volume 17 No 2 Juli 2021 \\ p-ISSN: 0216-938X e-ISSN: 2684-8414}

informasi pribadi setiap pengunjung serta waktu muat dari website tersebut harus cepat. Berdasarkan tanggapan responden serta profil responden dapat juga dapat ditarik sebuah kesimpulan bahwa kecenderungan konsumen wanita berumur 17 hingga 25 tahun yang menganggap website lebih berguna/bermanfaat jika dapat menjamin keamanan saat dalam transaksi, menjamin informasi pribadi pengunjung, serta memiliki fitur interaktif yang dapat membantu pengunjung, selain dari itu secara fenomena empiris juga dapat dilihat bahwa website sangat berguna bagi para calon customer ketika ingin mencari informasi ataupun melakukan transaksi atas produk yang dijual , hal ini didukung dengan tanggapan beberapa responden yang menyatakan bahwa website berguna dalam proses browsing ataupun transaksi.

\section{Pengaruh Ease of Use Terhadap Minat Beli}

Berdasarkan dari hasil uji t, dapat diketahui bahwa dalam penelitian ini variabel ease of use tidak memiliki pengaruh signifikan terhadap minat beli. Berdasarkan hasil tersebut maka hipotesis kedua yang dirumuskan oleh penulis yaitu ease of use berpengaruh signifikan terhadap minat beli tidak dapat diterima. Hal ini mendukung hasil penelitian terdahulu Liat dan Wuan (2014) yang menyatakan bahwa ease of use tidak memiliki pengaruh signifikan terhadap minat beli namun tidak sesuai dengan beberapa penelitian terdahulu seperti Rashid et al. (2018) dan Rahmawati et al. (2018) yang menyatakan bahwa ease of use memiliki pengaruh terhadap minat beli. Hasil uji $\mathrm{t}$ untuk variabel ease of use dinyatakan tidak signifikan dengan catatan nilai t hitung < daripada t tabel dan nilai signifikansi dari variabel ease of use $>0,05$. Tidak hanya itu berdasarkan persamaan regresi linier berganda ditemukan juga bahwa untuk nilai dari ease of use berupa negatif dimana dapat dinyatakan bahwa hubungan dari ease of use terhadap minat beli berupa negatif. Hal ini dapat dibahas lebih lanjut namun juga dapat menjadi sebuah pertimbangan dalam aspek kualitas website.

Pertama ease of use dalam penelitian ini meliputi 2 indikator utama yaitu ease of understanding serta intuitive operations yang dapat diartikan sebagai kemudahan pengertian serta operasi yang intuitif. Berdasarkan Loiacono et al. (2007) ease of understanding diasosiasikan dengan bagaimana halaman tampilan website bersifat mudah untuk dibaca atau dimengerti, sementara untuk intuitive operation meliputi apakah mudah bagi pengunjung website untuk mengoperasikan atau bernavigasi dalam website. Hasil penelitian ini menyatakan bahwa ease of use tidak berpengaruh signifikan terhadap minat beli dan dapat dikaitkan dengan beberapa pernyataan seperti berdasarkan (Ganguly et al.,2007) "if users perceive that a website is difficult to use, or the display of the website is complicated and ambiguous, they will show a lower online purchase intention".

Berdasarkan penelitian tersebut dapat ditemukan bahwa terdapat kecenderungan jika sebuah website cukup susah untuk digunakan, ambigu serta rumit maka timbul kemungkinan akan mengurangi minat beli calon konsumen. Pernyataan lainnya berdasarkan penelitian (Sari \& Setiaboedhi, 2017) dimana dalam hasil penelitian tersebut ditemukan bahwa ease of use tidak 


\section{SEGMEN Jurnal Manajemen dan Bisnis \\ Volume 17 No 2 Juli 2021 \\ p-ISSN: 0216-938X e-ISSN: 2684-8414}

berpengaruh signifikan dikarenakan timbul kemungkinan setiap responden sudah pernah berbelanja secara online sehingga dapat memahami prosedur dan tata cara berbelanja online. Hal ini memberikan dua kemungkinan mengapa ease of use dalam penelitian ini tidak berpengaruh secara signifikan, dimana pertama dikarenakan responden merasa website start up business mahasiswa cenderung rumit dan tidak mudah digunakan dan sesuai dengan penelitian Davis (1989) yang menyatakan bahwa jika seorang individu merasa suatu sistem tidak mudah digunakan, atau terlalu susah untuk dimengerti maka timbul kemungkinan individu tersebut tidak akan menggunakan sistem tersebut. Alasan lain ease of use tidak berpengaruh signifikan dikarenakan responden merasa bahwa website terlalu mudah untuk digunakan baik untuk responden yang pertama kali mengakses website tersebut, hal ini didukung dengan mayoritas responden penelitian yang berada di jangkauan umur 17 hingga 25 tahun dan cenderung sudah mengerti teknologi dan mengikuti perkembangannya.

Berdasarkan hal tersebut juga penulis akhirnya melakukan beberapa wawancara tambahan kepada responden yang pernah mengisi kuesioner penelitian dan bersedia untuk menjawab beberapa pertanyaan dari penulis. Hasil dari wawancara tersebut menjawab asumsi untuk pernyataan kedua yaitu ease of use dalam website tidak berpengaruh terhadap minat beli dikarenakan para responden cenderung sudah bisa menggunakan/bernavigasi dalam website meskipun merupakan pertama kali bagi para responden mengunjungi websit. Dimana bagi para responden yang telah diwawancarai menyatakan bahwa website berguna untuk kebutuhan mencari informasi atau transaksi seputar produk dari start up business yang bersangkutan dan sangat mudah untuk digunakan. Hal ini dapat menjawab asumsi atau dugaan yang timbul akan mengapa ease of use tidak berpengaruh signifikan terhadap minat beli dalam penelitian ini.

Meskipun ease of use dalam penelitian ini dinyatakan tidak berpengaruh signifikan namun indikator dari ease of use beserta respon dari para individu dapat menjadi sebuah pertimbangan untuk diterapkan dalam pembuatan website. Hal ini dikarenakan berdasarkan tanggapan responden yang telah dikumpulkan terdapat kecenderungan responden yang setuju bahwa website harus memiliki tampilan halaman yang mudah dibaca, serta mudah untuk dijalankan sebagai salah satu aspek kualitas website. Tanggapan dari responden juga menunjukkan bahwa kecenderungan responden wanita di umur 17 hingga 25 tahun lebih mengutamakan kemudahan dalam akses website hal ini didukung juga berdasarkan hasil kuesioner yang memiliki nilai mean tertinggi dari variabel lainnya.

\section{Pengaruh Entertainment Terhadap Minat Beli}

Berdasarkan hasil uji t, ditemukan bahwa variabel entertainment dalam penelitian ini memiliki pengaruh signifikan terhadap minat beli. Berdasarkan dari hasil tersebut maka hipotesis ketiga yang dirumuskan oleh penulis yaitu entertainment memiliki pengaruh signifikan terhadap minat beli dapat diterima. Hal ini didukung dengan salah satu penelitian terdahulu Rahmawati (2018) yang menyatakan bahwa variabel entertainment memiliki pengaruh signifikan 


\section{SEGMEN Jurnal Manajemen dan Bisnis \\ Volume 17 No 2 Juli 2021 \\ p-ISSN: 0216-938X e-ISSN: 2684-8414}

terhadap minat beli. Hasil penelitian ini dapat dibahas secara lebih dimulai dari indikator pernyataan yang digunakan untuk mewakili variabel entertainment yaitu visual appeal, innovativeness, serta emotional appeal. Visual appeal secara tidak langsung lebih mengarah ke aspek desain dari sebuah website dimana berdasarkan hasil penelitian yang telah dilakukan desain dari sebuah website menjadi salah satu hal yang diperhatikan dan mampu menarik konsumen (Gunarsih, 2011). Penerapan dari aspek visual appeal pada website start up business mahasiswa dapat dilihat berdasarkan desain atau tema yang diusung dalam website tersebut, dimana website-website tersebut menggunakan tema yang identik dengan produk yang dijual serta penggunaan palet warna yang sesuai dengan produk yang dijual berupa untuk lebih menyesuaikan desain dan tema yang dipakai.

Loiacono et al. (2007) menyatakan bahwa meskipun variabel entertainment tidak menjamin menumbuhkan minat transaksi konsumen namun hal ini sesuai dengan keinginan konsumen untuk tetap dihibur ketika dalam proses apapun seperti saat sedang menjelajah dalam website. Berdasarkan tanggapan responden mengenai variabel entertainment dapat disimpulkan beberapa hal, pertama terdapat kecenderungan bahwa profil responden wanita berada di kisaran umur 17 hingga 25 tahun lebih tertarik untuk mengunjungi website serta memberikan implikasi bahwa website yang mampu terlihat kreatif serta menarik akan lebih baik di mata konsumen, hal ini sesuai dengan beberapa penelitian terdahulu (Canziani \& Welsh, 2016 dan Chen et al, 2002) yang menyatakan bahwa website dapat mendapatkan nilai yang tinggi dalam aspek entertainment jika terlihat menyenangkan, menggunakan tema menarik, grafik yang bagus atau desain yang menarik. Tidak hanya itu berdasarkan karakteristik calon konsumen yang berumur 17 hingga 25 tahun cenderung dapat diimplikasikan bahwa konsumen berjenis kelamin wanita dengan umur 17 hingga 25 tahun lebih menilai aspek desain visual dari sebuah website serta tingkat kreatifitas dari website tersebut.

\section{Pengaruh Complementary Relationship Terhadap Minat Beli}

Berdasarkan hasil uji $\mathrm{t}$ dinyatakan bahwa variabel complementary relationship memiliki pengaruh signifikan terhadap variabel minat beli. Hal ini mendukung hipotesis keempat yang disusun oleh penulis yaitu complementary relationship memiliki pengaruh signifikan terhadap minat beli sehingga hipotesis tersebut dapat diterima. Hasil penelitian ini didukung dengan penelitian terdahulu Rahmawati (2018) yang menyatakan bahwa variabel complementary relationship memiliki pengaruh yang signifikan terhadap minat beli. Dalam aspek website complementary relationship diibaratkan sebagai faktor pelengkap dalam sebuah website, faktor-faktor pelengkap ini dapat berbentuk keuntungan yang didapatkan ketika menggunakan website, ataupun tingkat konsistensi gambaran dari website dengan perusahaan (Loiacono, 2007), ataupun fitur tambahan seperti tersedianya fitur transaksi online.

Octavia \& Tamerlane (2017) menjelaskan bahwa ketika customer berinteraksi dengan situs web terdapat kemungkinan mereka melakukan aktivitas yang berhubungan dengan teknologi tanpa 


\section{SEGMEN Jurnal Manajemen dan Bisnis \\ Volume 17 No 2 Juli 2021 \\ p-ISSN: 0216-938X e-ISSN: 2684-8414}

mendapat bantuan dari para karyawan, sehingga tampilan antarmuka situs web memegang peranan penting dalam transaksi online. Tidak hanya itu Ghafiki \& Setyorini (2017) mendefinisikan konten website akan bagaimana informasi, fitur dan services didesain dan dibentuk untuk mudah diakses oleh pengunjung web. Hal tersebut mendukung hasil penelitian yang telah dilakukan dimana ditemukan bahwa konsumen atau pengunjung cenderung mengutamakan adanya ketersediaan fiturfitur seperti transaksi online dalam sebuah website, serta didukung juga dengan deskripsi dari respon para responden yang cenderung sangat setuju dengan pernyataan website menyediakan fitur transaksi online. Tidak hanya itu salah satu responden yang telah diwawancarai juga menegaskan menurutnya menggunakan website cenderung lebih mudah dalam aspek melakukan aktivitas seperti transaksi ataupun menanyakan suatu informasi ,dimana dalam website tersedia fitur komplementer seperti live chat, dan meskipun pihak admin live chat tidak online email ataupun pertanyaan yang disampaikan akan tetap masuk dalam email admin dari pemilik website tersebut. Tidak hanya itu implikasi lain yang ditemukan berdasarkan tanggapan responden meliputi beberapa hal seperti, website dapat menggambarkan perusahaanya secara konsisten, dimana hal ini dapat diartikan bahwa kualitas website yang baik berdasarkan aspek complementary relationship meliputi kemampuan dari website tersebut untuk menggambarkan secara konsisten perusahaanya.

\section{IMPLIKASI TEORITIS DAN PRAKTIS}

Berdasarkan penelitian yang telah dilakukan ditemukan beberapa implikasi penelitian yang dapat diterapkan baik untuk start up business mahasiswa maupun untuk perusahaan lain serta tidak menutup kemungkinan para peneliti yang akan melanjutkan penelitian mengenai kualitas website dan minat beli. Hasil penelitian menyatakan bahwa terdapat pengaruh signifikan antara usefulness terhadap minat beli, hal ini diperkuat oleh beberapa indikator seperti trust dan response time yang mendorong/dapat meningkatkan minat beli seseorang. Beberapa implikasi yang dapat dipertimbangkan untuk diterapkan baik ke perusahaan seputar variabel usefulness yaitu, kualitas website didasari seberapa besar informasi yang disampaikan dapat memenuhi kebutuhan pengunjungnya. Kedua, kemampuan dari website untuk menjaga aktivitas transaksi yang dilakukan individu dalam website serta menjaga informasi pribadi dari pengunjung.

Ketiga yaitu waktu muat sebuah website juga menjadi faktor kualitas website yang penting, terlebih berdasarkan Loiacono et al. (2007) menyatakan bahwa waktu muat yang lama dapat membuat pengunjung website tersebut tidak mengunjungi atau tidak mengakses website tersebut. Terakhir yaitu adanya fitur interaktif yang dapat membantu pengunjung atau calon konsumen, seperti system search engine, filter dan sebagainya. Hal-hal ini dapat menjadi sebuah pertimbangan untuk para perusahaan yang membentuk suatu website untuk mencapai kualitas website yang baik.

Implikasi berikutnya berdasarkan hasil variabel ease of use, dimana meskipun 


\section{SEGMEN Jurnal Manajemen dan Bisnis \\ Volume 17 No 2 Juli 2021 \\ p-ISSN: 0216-938X e-ISSN: 2684-8414}

dalam penelitian ini variabel ease of use digolongkan tidak berpengaruh signifikan terhadap minat beli. Tetapi berdasarkan hasil tanggapan responden terdapat beberapa hal yang dapat dipertimbangkan untuk digunakan dalam sebuah website. Pertama halaman tampilan dan tulisan dalam website terlihat serta mudah dibaca, hal ini menjadi salah satu hal penting bagi sebuah website dikarenakan jika sebuah website tidak memiliki teks ataupun laman yang mudah dibaca maka secara tidak langsung pengunjung tidak akan pergi ke website tersebut dengan alasan kesulitan bagi para pengunjung untuk membaca ataupun melihat teks dalam website.

Kedua yaitu kemudahan untuk menjalankan ataupun menggunakan website, tentunya hal ini menjadi salah satu hal yang perlu diimplementasikan kepada setiap website. Hal ini dikarenakan jika pengunjung atau pembeli melakukan kunjungan ke website namun tidak bisa sama sekali menggunakannya, maka tentu hasilnya pengunjung tersebut tidak akan mencoba menggunakan website tersebut lagi. Pernyataan tersebut sejalan dengan Davis (1989) dimana jika suatu sistem susah untuk digunakan maka kemungkinan besar individu tidak akan menggunakan sistem tersebut, dalam konteks ini merupakan website.

Berikutnya implikasi berdasarkan variabel entertainment, dimana di dalam penelitian ini entertainment berpengaruh signifikan terhadap minat beli. Terdapat beberapa hal yang dapat dipertimbangkan start up business dalam membentuk website berdasarkan aspek entertainment, pertama berdasarkan tanggapan responden website harus dapat menampilkan desain visual yang menarik ataupun inovatif, dengan catatan semakin menarik desain dari website semakin berpotensi untuk menarik target konsumen perusahaan. Kedua kreatifitas dalam website termasuk dalam kualitas website, dimana semakin kreatif website dibentuk maka akan semakin menarik minat konsumen. Kreatifitas dapat diterapkan dalam berbagai hal seperti penerapan dalam aspek desain, ataupun dalam proses navigasi website. Terakhir entertainment juga menyatakan kemampuan website untuk memberikan aspek emosional baik rasa senang, ataupun sedih juga dapat menjadi salah satu bagian dari kualitas website.

Implikasi terakhir berdasarkan variabel complementary relationship dimana variabel complementary relationship dalam penelitian ini dinyatakan berpengaruh signifikan terhadap minat beli. Beberapa pertimbangan yang dapat diterapkan baik untuk start up business yaitu, pertama memastikan konsistensi dari website dalam mencerminkan perusahaan. Yang dimaksud yaitu kemampuan website untuk menggambarkan perusahaan secara konsisten dan tidak berbeda dari web dan kenyataan. Kedua kemampuan dari website untuk menyediakan fitur transaksi online, fitur transaksi online meskipun dapat dikategorikan dalam aspek usefulness namun juga tergolong dalam complementary relationship serta lebih ke arah komplementer. Ketiga menciptakan website yang dapat digunakan oleh pengunjung untuk menyelesaikan keperluan bisnisnya terhadap perusahaan pemilik website, contohnya pengunjung ingin berbicara dengan pihak perusahaan ataupun melakukan transaksi apapun. Terakhir yaitu website dapat menjadi 


\section{SEGMEN Jurnal Manajemen dan Bisnis \\ Volume 17 No 2 Juli 2021 \\ p-ISSN: 0216-938X e-ISSN: 2684-8414}

aternatif selain menghubungi customer service, dimana salah satu kualitas website yang baik berdasarkan indikator complementary relationship yaitu menjadikan website sebagai kontak alternatif.

\section{SIMPULAN}

Berdasarkan hasil penelitian dan pembahasan mengenai variabel usefulness, ease of use, entertainment dan complementary relationship, dapat dibentuk sebuah kesimpulan sebagai berikut:

1. Variabel usefulness dinyatakan memiliki pengaruh yang positif terhadap minat beli produk start up business mahasiswa. Berdasarkan hasil dari penelitian ini ditarik kesimpulan apabila usefulness mengalami peningkatan maka minat beli juga akan ikut meningkat, sehingga variabel usefulness menjadi salah satu faktor yang dipertimbangkan dalam minat beli konsumen.

2. Variabel ease of use dinyatakan tidak memiliki pengaruh yang signifikan terhadap minat beli produk start up business mahasiswa. Hal ini menjadi pertimbangan bahwa minat beli seorang konsumen belum tentu timbul karena ease of use.

3. Variabel entertainment dinyatakan memiliki pengaruh yang positif terhadap minat beli produkstart up business mahasiswa. Hasil dari persamaan regresi yang telah dibahas juga menunjukkan bahwa variabel entertainment memiliki pengaruh positif terhadap minat beli, sehingga dapat disimpulkan bahwa setiap ada peningkatan pada entertainment maka minat beli juga akan meningkat. Hal ini menjadi pertimbangan bahwa minat beli konsumen dapat timbul karena entertainment.

4. Variabel complementary relationship dinyatakan memiliki pengaruh signifikan terhadap minat beli produk starup up business mahasiswa. Dengan demikian dapat disimpulkan bahwa complementary relationship memiliki pengaruh positif sehingga dapat disimpulkan dalam setiap peningkatan complementary relationship maka minat beli akan mengalami peningkatan juga. Hal ini menjadi sebuah pertimbangan bahwa minat beli konsumen dapat timbul karena complementary relationship.

\section{KETERBATASAN PENELITIAN}

Tentunya dalam penelitian terdapat beberapa keterbatasan penulis dalam menjalankan penelitian ini. Diantaranya yaitu beberapa sampel penelitian yang tidak dapat digunakan dikarenakan tidak memenuhi kriteria yang telah ditetapkan dan sedikitnya penelitian terdahulu yang memiliki fokus pembahasan seputar variabel usefulness, ease of use, entertainment dan complementary relationship serta keterkaitannya terhadap variabel minat beli. Selain itu, penelitian ini hanya dilakukan pada ruang lingkup Universitas Ciputra, sehingga dibutuhkan adanya penelitian lebih lanjut yang menguji pengaruh kualitas website terhadap minat beli di wilayah yang lebih luas

\section{DAFTAR PUSTAKA}

Ahmad, A., \& Khan, M. N. (2017). Developing a website quality scale: a confirmatory factor analytic approach. Journal of Internet Commerce, 104-126. 


\section{SEGMEN Jurnal Manajemen dan Bisnis \\ Volume 17 No 2 Juli 2021 \\ p-ISSN: 0216-938X e-ISSN: 2684-8414}

Ahmad, A., Rahman, O., \& Khan, M. N. (2017). Exploring the role of website quality and hedonism in the formation of e-satisfaction and e-loyalty: evidence from internet users in India. Journal of Research in Interactive Marketing, 246-267.

Akram, U., Hui, P., Khan, M. K., Tanveer, Y., Mehmood, K., \& Ahmad, W. (2017). How website quality affects online impulse buying: moderating effects of sales promotion and credit card use. Journal of Marketing and Logistics.

Ali, F. (2016). Hotel website quality, perceived flow, customer satisfaction and purchase intention. Journal of Hospitality and Tourism Technology, 213-228.

Ajzen, I. (1991), "The theory of planned behavior", Organizational Behavior and Human Decision Processes, Vol. 50, pp. 179-211.

Ajzen, I. (2001), "Nature and operations of attitudes", Annual Review of Psychology, Vol. 52, pp. 27-27.

Ajzen and Fishbein, M. (1980) 'Understanding attitudes and predicting social behaviour'. Available at: http://www.citeulike.org/group/38/ar ticle/235626 (Accessed: 9 May 2017).

Arikunto, S. (2006). Prosedur penelitian suatu pendekatan praktik. Jakarta: Rineka Cipta.

Athapathth, \& Kulathunga. (2018). Factors affecting online purchase intention: a study of sri lankan online customers.
International Journal of Scientific \& Technology, 120-128.

Canziani, B. F., \& Welsh, D. H. (2016). Website quality for SME wineries: measurement insights. Journal of Hospitality and Tourism Technology, 266-280.

Crescimanno, M., Galati, A., Siggia, D., \& Tinervia, S. (2016). Website quality and internal business factors: an empirical investigation in the italian wine industry. International Journal of Wine Business Research, 1-18.

Davis, F. D. (1989). Perceived usefulness, perceived ease of use, and user acceptance of information technology. 319-340.

Davis, F. D., Bagozzi, R. P., \& Warshaw, P. R. (1989). User acceptance of computer technology: a comparison of two theoretical models. Management Science, 982-1003.

Ganguly, B., Dash, S. B., Cyr, D., \& Head, M. (2010). The effects of website design on purchase intention in online shopping: the mediating role of trust and the moderating role of culture. International Journal Electronic Business, 302-330.

Ghafiki, R., \& Setyorini, R. (2017). Pengaruh kualitas website terhadap keputusan pembelian pada situs bukalapak.com. E-proceeding of Management, 678686.

Hair, J. F., Black, W. C., Babin, B. J., \& Anderson, R. E. (2014). Multivariate Data Analysis. Edinburgh Gate Harlow: Pearson Education Limited.

Jeon, M. M., \& Jeong, M. (2017). Customer's perceived website service quality and 


\section{SEGMEN Jurnal Manajemen dan Bisnis \\ Volume 17 No 2 Juli 2021 \\ p-ISSN: 0216-938X e-ISSN: 2684-8414}

its effects on e-loyalty. International Journal of Contemporary Hospitality Management, 438-457.

Kasiram, M. (2008). Metodologi Penelitian. Malang: UIN-Maliki Press.

Kim, H., \& Niehm, L. S. (2009). The impact of website quality on information quality, value, and loyalty intentions in apparel retailing. Journal of Interactive Marketing, 221-233.

Liat, C. B., \& Wuan, Y. S. (2014). Factors Influencing Consumers' Online Purchase Intention: A Study among University Students in Malaysia. International Journal of Liberal Arts and Social Science, 121-133.

Loiacono, E. T., Watson, R. T., \& Goodhue, D. L. (2007). WebQual: an instrument for consumer evaluation of web sites. International Journal of Electronic Commerce, 51-87.

Octavia, D., \& Tamerlane, A. (2017). The influence of website quality on online purchase intentions on agoda.com with e-trust as a mediator. 9-14.

Raad, W., Rashid, N., Hayder.A.ALiamy, S.Khalid, I., Al-shami, S. A., \& Alaraji, Z. (2018). The role of web design towards influence purchase intention in hotel industry. Journal of Design, Art and Communication, 111.

Rahmawati, N. A., Suroso, A. I., \& Ramadhan, A. (2018). Factors influencing the purchase intention in online organic fruit and vegetable stores. Jurnal Manajemen \& Agribisnis, 209-220.

Rezende, N. E., Moura, L. R., Vasconcelos, F. C., \& Cunha, N. R. (2017). Proposition an test of quality assessment extension WebQual model in Brazil. Review of European Studies, 74-90.

Schiffman, L., \& Kanuk, L. L. (2008). Perilaku Konsumen. Jakarta: PT Indeks.

Septanto, A. F., SE.MM, A. T., \& MM, D. C. (2018). Pengaruh kualitas produk, citra merek, persepsi harga terhadap emotional response dengan minat beli sebagai variabel intervening. 140157.

Siddiqui, K. (2013). Heuristics for Sample Size Determination in Multivariate Statistical Techniques . World Applied Sciences Journal, 285-287.

Sitanggang, F. C., \& Rahmat Hidayat, S. (2018). Pengaruh electronic word of mouth (EWOM) dan kualitas website terhadap minat minta beli (studi kasus pada WARUNK UPNORMAL di kota Bandung tahun 2018). Eproceeding of Applied Science, 348356.

Tsao, W.C., Hsieh, M.-T., \& Lin, T. M. (2016). Intensifying online loyalty! the power of website quality and the perceived value of consumer/seller relationship. Internation Journal of Contemporary Hospitality Management, 1987-2010. 